\title{
The effect of characteristics differences in vertical pair of executives and equity incentives on enterprise performance
}

\author{
$Y u \mathrm{Lu}^{1, *}$, and Ruijie $\mathrm{Xu}^{1}$ \\ College of Business Administration, Capital University of Economics and Business, 100070, Beijing, \\ China
}

Keywords: Characteristics difference in vertical pair of executives, Equity incentive, Business performance.

\begin{abstract}
Taken the leading enterprises in the Shanghai and Shenzhen A-share listed companies from 2013 to 2017 as the research samples, the effect of characteristics differences in vertical pair of executives and equity incentives on enterprise performance was empirically analyzed. Constructing multiple linear regression model tested hypothesis. The results show that the interaction between equity incentives and the difference in age of vertical pair of senior executives has a significant negative impact on enterprise performance; the interaction between equity incentives and the difference in education of vertical pair of senior executives has a significant positive impact on enterprise performance.
\end{abstract}

\section{Introduction}

As the most advanced incentive tool at present, equity incentives have been used by many companies around the world and have achieved good results. However, judging from the practical effects in China, due to the problems of the macro environment and the design of incentive schemes, many enterprises have not significantly improved their performance after the implementation of equity incentives. The reason may be that the role of senior executive equity incentives are not played alone, but also affected by factors such as culture, policies, company structure, and the characteristics of managers.

Based on this, by searching a large number of cases of executive equity incentive failures, it is found that many executive incentives are not significant, most of them are mechanically copied according to the theory and not combined with their own characteristics to implement customized incentive programs. In response to this problem, some scholars have previously discovered and studied the regulatory effects of executive characteristics. For example, Jie Bai (2013) found that the level of executive education has a positive interaction on company performance, and the age of executives and equity incentives have a negative interaction on company performance[1].

\footnotetext{
*Corresponding author: luyustudents@163.com
} 


\section{Hypothesis}

This article studies the effect of the interaction between characteristics differences in vertical pair of executives and equity incentives on enterprise performance from an endogenous perspective. It mainly draws on the research of Long Zhang and Hong Liu (2009) [2], Lin Yang (2014) [3] and Weifeng He (2015) [4], etc., and considers the availability of data. The difference in age and education of vertical pair of executives were used as moderators to study the moderating effects of differences in vertical pair of executives' team and equity incentives on enterprise performance.

First of all, from the perspective of the difference in age of vertical pair of senior executives, it can be known from the similarity attraction theory that the larger difference in age of vertical pair of the chairman-executive team is, the more likely to have conflicts due to different ideas is. Yawei Liu and Huayun Zhai (2017) also confirmed that the generation gap between the upper and lower levels will be formed if the difference in age of vertical pair of executives is too large, which is not conducive to the improvement of enterprise performance. Moreover, if there is a big difference in age of vertical pair of executives, it will also have a negative impact on the effect of the implementation of equity incentive [5]. Hong Huang and Lin Liu (2014) also found that when there is a large heterogeneity in the executive team, many young managers use equity incentives as a cash tool and resign after receiving equity incentives to obtain cash [6]. Hence, when there is a big difference in the age of senior management team, it is not conducive to the implementation of equity incentives.

Therefore, hypothesis H1: The interaction between equity incentives and the difference in age of vertical pair of senior executives has a negative impact on enterprise performance.

Secondly, from the perspective of the difference in education of vertical pair of senior executives, it can provide diversified information to the team and team members have more levels of understanding on the information. The collision and fusion of different views within the team can form a strong ability to solve complex and uncertain problems, thereby improving enterprise performance. Yawei Liu and Huayun Zhai (2017) show that the difference in education of vertical pair of senior executives has a positive impact on the effect of the implementation of equity incentives [5]. Ying Sun and Yi Zhang (2018) found that senior executives with higher education level, having more knowledge and ability to seek opportunities and make judgment choices, more inclined to view the development of the enterprise from a long-term perspective, are more receptive to long-term interest oriented equity incentive and have a greater effect on improving corporate performance [7].

Therefore, hypothesis H2: The interaction between equity incentives and the difference in education of vertical pair of senior executives has a positive impact on enterprise performance.

\section{Research design}

\subsection{Model design}

Based on previous studies, the following multiple linear regression model is constructed to test hypothesis $\mathrm{H} 1$ and $\mathrm{H} 2$.

$$
\begin{aligned}
& T Q=\mathrm{a}+\mathrm{b}_{1} M S R+\mathrm{b}_{2} \text { Vage }+\mathrm{b}_{3} M S R \times \text { Vage }+\mathrm{b}_{4} \text { Lever }+\mathrm{b}_{5} \text { Size }+\mathrm{b}_{6} B D S+\mathrm{b}_{7} \text { Cash }+\varepsilon \\
& T Q=\mathrm{a}+\mathrm{b}_{1} M S R+\mathrm{b}_{2} \text { Vedu }+\mathrm{b}_{3} M S R \times V e d u+\mathrm{b}_{4} \text { Lever }+\mathrm{b}_{5} \text { Size }+\mathrm{b}_{6} B D S+\mathrm{b}_{7} \text { Cash }+\varepsilon
\end{aligned}
$$




\subsection{Variable interpretation}

The specific definitions of all variables are shown in Table 1.

Table1. Variable definition table.

\begin{tabular}{|c|c|c|c|}
\hline $\begin{array}{c}\text { Variable } \\
\text { properties }\end{array}$ & Variable name & $\begin{array}{c}\text { Variable } \\
\text { symbol }\end{array}$ & Variable measurement method \\
\hline $\begin{array}{c}\text { Dependent } \\
\text { variable }\end{array}$ & Enterprise performance & $T Q$ & Tobin $Q$ value \\
\hline $\begin{array}{l}\text { Independen } \\
\mathrm{t} \text { variable }\end{array}$ & Equity incentive & $M S R$ & Managers'shareholding / total shares \\
\hline \multirow{2}{*}{ Moderator } & $\begin{array}{l}\text { Difference in age of vertical pair } \\
\text { of senior executives }\end{array}$ & Vage & $\begin{array}{c}\text { Absolute value of the difference between the } \\
\text { chairman's age and the average age of senior } \\
\text { executives }\end{array}$ \\
\hline & $\begin{array}{c}\text { Difference in education of } \\
\text { vertical pair of senior executives }\end{array}$ & Vedu & $\begin{array}{l}\text { Absolute value of the difference between the } \\
\text { chairman's education and the average of senior } \\
\text { executives's education }\end{array}$ \\
\hline \multirow{4}{*}{$\begin{array}{l}\text { Control } \\
\text { variable }\end{array}$} & Corporate financial leverage & Lever & Asset liability ratio \\
\hline & Company Size & Size & Natural logarithm of the company's total assets \\
\hline & Board size & $B D S$ & Number of board members \\
\hline & Cash flow level & Cash & $\begin{array}{c}\text { Monetary capital / Total assets at the end of the } \\
\text { period }\end{array}$ \\
\hline
\end{tabular}

\subsection{Sample source and data selection}

Leading companies in the Shanghai-Shenzhen A-share listed industry from 2013 to 2017 were selected as research samples. They were selected based on the following principles: (1) excluding financial enterprises; (2) excluding enterprises with missing relevant data. In order to eliminate the effects of extreme values, all variables are processed to exclude extreme values.

\section{Analysis of empirical results}

\subsection{Descriptive statistics of the main variables}

Table 2 shows the descriptive statistics of the main variables in this article. It can be seen that there is still a phenomenon of zero shareholding of senior executives in China. From the perspective of the average of equity incentive, the average shareholding of executives is still very low, indicating that equity incentive measures need to be improved and strengthened. From characteristics differences in vertical pair of senior executive team, it can be seen that there is a large difference in age and tenure between the chairman and senior executive team in China and the mean is also large. The large age difference is more likely to cause divergences due to generation gap, which is not conducive to the improvement of enterprise performance. The education difference between the chairman and the senior executive team is small and the average difference is less than 1. From the average education of the chairman and the senior executive team, most of them are above the undergraduate level, indicating that the average education background of the senior executive team in China has a general improvement, which is more conducive to the improvement of enterprise performance. 
Table 2. Descriptive statistics of main variables.

\begin{tabular}{|c|c|c|c|c|c|}
\hline Variable name & $\mathbf{N}$ & Min & Max & Mean & Standard deviation \\
\hline$T Q$ & 206 & 0.71 & 8.11 & 1.86 & 1.24 \\
\hline MSR & 206 & 0 & 10.34 & 0.89 & 2.08 \\
\hline Vage & 206 & 0 & 14 & 5.18 & 3.37 \\
\hline Vedu & 206 & 0 & 2.45 & 0.66 & 0.42 \\
\hline Lever & 206 & 0.16 & 0.88 & 0.50 & 0.17 \\
\hline Size & 206 & 5.38 & 8.26 & 6.60 & 0.58 \\
\hline BDS & 206 & 5 & 15 & 9.43 & 2.05 \\
\hline Cash & 206 & 0 & 2.25 & 0.19 & 0.22 \\
\hline
\end{tabular}

\subsection{Correlation analysis of variables}

Table 3 is the correlation analysis of each variable. From Table 3, it can be seen that there is a non-significant negative correlation between the age difference of the senior executive team and the TQ value. It also confirms the hypothesis that a large difference in age of vertical pair of senior executives is easy to form generation gap and increase conflicts, which is not conducive to the stable operation of enterprises. However, the correlation coefficient between the difference in education of vertical pair of senior executives and the TQ value is 0.137 , which is significant at the level of $10 \%$. It indicates that under the premise of conforming to the social norms theory, a large difference in education of vertical pair of senior executives is beneficial to the collision of different levels of knowledge and the improvement of business operation and decision-making, which can improve enterprise performance.

Table 3. Correlation analysis of variables.

\begin{tabular}{|c|c|c|c|c|c|c|c|c|}
\hline Variable name & $\mathbf{1}$ & $\mathbf{2}$ & $\mathbf{3}$ & $\mathbf{4}$ & $\mathbf{5}$ & $\mathbf{6}$ & $\mathbf{7}$ & $\mathbf{8}$ \\
\hline (1) $\boldsymbol{T Q}$ & 1 & & & & & & & \\
\hline (2) $\boldsymbol{M S R}$ & $.314^{* *}$ & 1 & & & & & & \\
\hline (3) Vage & -.067 & -.115 & 1 & & & & & \\
\hline (4) Vedu & $.137^{*}$ & $.158^{*}$ & -.078 & 1 & & & & \\
\hline (5) Lever & $-.521^{* *}$ & $-.189^{* *}$ & .126 & $-.180^{*}$ & 1 & & & \\
\hline (6) Size & $-.498^{* *}$ & $-.270^{* *}$ & .020 & -.068 & $.213^{* *}$ & 1 & & \\
\hline (7) BDS & $-.201^{* *}$ & .094 & -.025 & -.078 & $.160^{*}$ & $.147^{*}$ & 1 & \\
\hline (8) Cash & $.249^{* *}$ & .056 & -.067 & -.009 & -.035 & -.130 & -.081 & 1 \\
\hline
\end{tabular}

Note: $* * *, * * *$ indicate significant levels at $10 \%, 5 \%$, and $1 \%$, respectively

\subsection{Analysis of regression results}

Table 4 is the analysis of multiple regression results. Models 1 and 2 respectively verify hypotheses 1 and 2 . Model 1 tests the effect of the interaction between equity incentives and the difference in age of vertical pair of senior executives on enterprise performance. From the empirical results of Model 1, it can be seen that the coefficient of the interaction term between equity incentives and the difference in age of vertical pair of senior executives is -0.003 , which is significant at the level of $5 \%$. It indicates that the interaction between equity incentives and the difference in age of vertical pair of senior executives has a negative impact on enterprise performance, which validates Hypothesis 1 of this article. Model 2 tests the effect of the interaction between equity incentives and the difference in education of vertical pair of senior executives on enterprise performance. From the empirical results of model 2, it can be seen that the coefficient of the interaction term between equity incentives and the difference in education of vertical pair of senior executives is 0.165 , which is significant at 
the level of 5\%. It shows that the interaction between equity incentives and the difference in education of vertical pair of senior executives has a positive impact on enterprise performance, which validates Hypothesis 2 of this article.

Table 4. Analysis of regression results.

\begin{tabular}{|c|c|c|}
\hline \multirow{2}{*}{ Variable name } & \multicolumn{2}{|c|}{$\boldsymbol{T Q}$} \\
\cline { 2 - 3 } C & $8.097^{* * *}$ & $\mathbf{3}$ \\
\hline \multirow{2}{*}{ MSR } & $(10.269)$ & $8.376^{* * *}$ \\
& $0.225^{* * *}$ & $(10.552)$ \\
\hline \multirow{2}{*}{ Vage } & $(3.330)$ & -0.036 \\
& 0.023 & $(-0.589)$ \\
\hline \multirow{2}{*}{ Vedu } & $(1.140)$ & \\
\hline \multirow{2}{*}{ MSR*Vage } & & -0.105 \\
& & $(-0.640)$ \\
\hline \multirow{2}{*}{ MSR*Vedu } & $-0.003^{* *}$ & \\
\hline \multirow{2}{*}{ Lever } & $(-2.321)$ & $0.165^{* *}$ \\
& & $(2.329)$ \\
\hline \multirow{2}{*}{ Size } & $-2.767^{* * *}$ & $-2.752^{* * *}$ \\
\hline \multirow{2}{*}{ BDS } & $(-7.248)$ & $-0.7201)$ \\
\hline \multirow{2}{*}{ Cash } & $-0.716^{* * *}$ & $(-6.266)$ \\
\hline Adjustment $\mathbf{R}^{\mathbf{2}}$ & $(-6.149)$ & $-0.055^{*}$ \\
\hline $\mathbf{N}$ & -0.53 & $(-1.726)$ \\
\hline & $(-1.650)$ & $1.026^{* * *}$ \\
& $1.019^{* * *}$ & $(3.581)$ \\
\hline
\end{tabular}

Note: $* * *, * * *$ indicate significant levels at $10 \%, 5 \%$, and $1 \%$, respectively

\section{Summary}

First of all, the interaction between equity incentives and the difference in age of vertical pair of senior executives has a negative impact on enterprise performance. The main reason is that the large age difference is more likely to cause divergences and conflicts due to generation gap. If equity incentives are implemented at this time, the senior executive team will have greater rights, indirectly reducing the authority of the chairman. This will increase such conflicts and is not conducive to the improvement of enterprise performance.

Secondly, the interaction between equity incentives and the difference in education of vertical pair of senior executives has a positive impact on enterprise performance. From the current social reality, in general, the education of the senior management team is equal to or higher than that of the board chairman. The larger difference in education of vertical pair of senior executives indicates the higher education level of the senior management team. For the senior management team with highly education background, paying more attention to the long-term interests of the enterprise, they are more willing to accept the flexible part of the salary design and the long-term interest-oriented equity incentives.

This research was financially supported by Capital University of Economics and Business basic research funding for Beijing city universities. 


\section{References}

1. J. Bai. Communication of Finance and Accounting, vol.10, 53-55, (2013).

2. L. Zhang, H. Liu. Management World, vol.4, 108-118, (2009).

3. L. Yang. Nankai Business Review, vol.17(01), 134-144, (2014).

4. W. F. He. Nankai Business Review, vol.18 (01), 141-151, (2015).

5. Y. W. Liu, H. Y. Zhai. Science \& Technology Progress and Policy, vol.34(14), 104-111, (2017).

6. H. Huang, L. Liu. Theoretical Scope, vol.1, 202-211, (2013).

7. Y. Sun, Y. Zhang. Financial Research, vol.3, 76-86, (2018). 